\title{
Motif Ekonomi Etnis Karo di Kawasan Sekitar Universitas Sumatera Utara
}

\author{
Karo Ethnic Economic Motives in the Area Around the \\ University of North Sumatra \\ Muhammad Adenan Ginting, Badaruddin \& Zulkifli Lubis
}

\author{
Program Studi Magister Studi Pembangunan, Fakultas Ilmu Sosial Dan Ilmu Politik \\ Universitas Sumatera Utara, Indonesia
}

Diterima: 4 Januari 2020; Disetujui: 25 Maret 2020; Diterbitkan: 1 Juli 2020. \begin{abstract}
Abstrak
Penelitian ini bertujuan untuk melihat, motif ekonomi yang dimiliki etnis karo dalam berkembang dan bertahan di kawasan USU. Jenis Penelitian ini menggunakan pendekatan kualitatif, lokasi Penelitian berada di Jalan Jamin Ginting Medan atau secara khusus di kawasan Padang Bulan, tepatnya dari simpang kampus hingga simpang Jalan Harmonika dan kawasan Jalan Pembangunan hingga simpang Kampung Susuk. Hasil penelitian menunjukkan bahwa motif yang mempengaruhi etnis karo untuk bertahan adalah tanah yang mereka miliki sebagai warisan dan meyakini bahwa tanah memiliki ruh yang hidup (ertendi); lahan yang strategis dengan Keberadaan USU sebagai daya Tarik usaha mereka. motif yang mempengaruhi etnis karo untuk berkembang adalah lebih melihat peluang jangka pendek usaha mereka untuk sekedar bertahan hidup, hanya melihat peluang yang tersedia dan hanya mampu menyediakan kebutuhan mahasiswa sesuai dengan perkembangan zaman. Kesimpulan dari penelitian iani adalah Etnis Karo bertahan di kawasan sekitar Universitas Sumatera karena memiliki motif kuat dalam diri mereka, bagaimana mereka mempertahankan aset yang mereka miliki. Etnis karo berkembang karena melihat peluang yang tersaji. Sebuah karakter yang menjadi temuan lapangan bagaimana etnis karo yang senang berjudi dengan keberuntungan diimplementasikan dalam cara mereka melihat peluang usaha. USU sebagai peluang disadari sebagai jalan mereka untuk meraup keuntungan dan mengembangkan usaha.
\end{abstract}

Kata Kunci: Motif Ekonomi, Etnis Karo, Universitas Sumatera Utara

\begin{abstract}
This study aims to see the economic motives of the Karo ethnic group in developing and surviving in the USU region. This type of research uses a qualitative approach, the research location is in Jalan Jamin Ginting Medan or specifically in the Padang Bulan area, precisely from the campus intersection to the Harmonika Road intersection and the Road Development area to the Kampung Susuk intersection. The results showed that the motives that influenced the ethnic karo to survive were the land they owned as an inheritance and believed that the land had a living spirit (ertendi); strategic land with the existence of USU as the main attraction of their business. the motive influencing the ethnic karo to develop is to look at the short-term opportunities of their efforts to just survive, only see the opportunities available and only be able to provide the needs of students in accordance with the times. The conclusion from the iani research is that the Karo Ethnic survive in the area around the University of Sumatra because they have strong motives in themselves, how they maintain their assets. Karo ethnic develops because of the opportunities presented. A character that is found in the field of how ethnic karo who love to gamble with luck is implemented in the way they see business opportunities. USU as an opportunity was recognized as their way to reap profits and develop businesses.
\end{abstract}

Keywords: Economic Motives, Ethnic Karo, University of North Sumatra.

How to Cite: Ginting, M.A, Badaruddin \& Lubis, Z. (2020). Motif Ekonomi Etnis Karo di Kawasan Sekitar Universitas Sumatera Utara. PERSPEKTIF, 9 (2): 130-148

\begin{tabular}{lr}
\hline${ }^{*}$ Corresponding author: & ISSN 2085-0328 (Print) \\
E-mail: adenan.ag.ag@gmail.com & ISSN 2541-5913 (online)
\end{tabular}




\section{PENDAHULUAN}

Penelitian ini mengambil tema tentang motif ekonomi Etnis Karo di kawasan sekitar Universitas Sumatera Utara (USU). Pengambilan tema ini berdasarkan ketertarikan peneliti tentang etos kerja yang dimiliki Etnis Karo dan upaya apa yang mereka lakukan untuk beradaptasi terhadap pembangunan yang ada di kawasan sekitar Universitas Sumatera Utara. Konsep adaptasi yang ingin dilihat disini bagaimana mereka bertahan dan berkembang.

Tema penelitian ini mengambil latar di kawasan sekitar USU. Kawasan ini secara administrasi merujuk pada Kecamatan Medan Baru. Pengambilan latar ini dilatarbelakangi oleh mayoritas penduduk yang beretnis Karo yang bertahan dengan lajunya pembangunan kota, dimana mereka ikut beradaptasi terhadap perkembangan yang terjadi dikawasan ini. Kawasan USU dipilih karena peneliti melihat kawasan ini mayoritas di huni oleh etnis Karo dan mereka bekerja dan berusaha dengan menyediakan kebutuhan-kebutuhan dari mahasiswa USU seperti, bahan kuliah, jasa print out, kuliner dan lain sebagainya, padahal potensi untuk menjual lahan mereka lebih strategis. Hal ini dibuktikan dengan penelitian pendahuluan yang peneliti lakukan. Dimana dari hasil penelitian pendahuluan tersebut terdapat 2 kawasan yang berbatasan langsung dengan tembok USU yaitu Jalan Jamin Ginting terdapat 84 orang dari etnis Karo telah mengusahakan lahannya untuk menjadi usaha dan Jalan Pembangunan terdapat 50 orang dari etnis Karo juga telah mengusahakan lahannya baik untuk usaha sendiri maupun disewakan.

Terkait motif ekonomi etnis Karo dan bagaimana etnis tersebut bertahan dan berkembang, tentu tidak bisa terlepas dari akar sejarah bagaimana etnis tersebut menghuni wilayah tersebut. Sebelum berbicara tentang bagaimana hal tersebut menjadi sisi yang menarik, sebagai bahan perbandingan maka peneliti melihat bagaimana etnis Tionghoa bertahan dalam membangun bisnis mereka.

Sebagai kelompok minoritas etnis Tionghoa mampu menunjukkan kapasitasnya. Tidak dapat dipungkiri, bahwa roda perekonomian khususnya dunia bisnis merupakan lahan yang tumbuh subur bagi etnis Tionghoa. Saat ini mereka mampu merajai dunia bisnis dalam negeri. Data menunjukkan bahwa etnis Tionghoa menguasai $80 \%$ perekonomian Indonesia. Bisnis bagi etnis Tionghoa merupakan roda perekonomian yang penting untuk memenuhi kebutuhan hidup. Ruang lingkup bisnis yang dijalankan oleh etnis Tionghoa terbilang luas, mulai dari bisnis perhotelan, bank, properti, elektronik, otomotif sampai aktifitas distribusi (Rizki, 2012)

Hampir setiap bidang usaha yang dimiliki individu dengan etnis Tionghoa berjalan dengan baik dan sukses. Ada juga memang yang gagal dalam usaha yang dijalankan, tetapi tidak banyak bila dibandingkan dengan usaha Etnis Tionghoa yang berjalan baik dan sukses. Seorang wirausaha etnis Tionghoa tersebut memiliki karakteristik personal, gaya manajerial serta nilai-nilai sosial dan kultural yang memberikan kontribusi kepada wirausaha Tionghoa secara umum (Riski, 2018).

Wirausahawan Tionghoa cenderung bersifat dinamis sekaligus pragmatis, fleksibel dan pandai menempatkan diri serta ulet. Hal ini sangat membantu mereka bertahan dalam lingkungan bisnis yang kompetitif bahkan dalam kondisi yang bergejolak sekalipun. Etnis Tionghoa tersebut mampu dan mau melayani serta mengembangkan efisiensi, membina hubungan dengan pelanggan dan serta pemegang saham lainnya dengan tetap menempatkan diri secara berhati-hati. Gaya manajemen Tionghoa sangat menekankan human relationship. Bahkan secara spesifik hubungan bisnis Tionghoa biasanya didasarkan pada persahabatan, 
kesetiaan dan kepercayaan yang tinggi. Pada level usaha kecil, bisnis Tionghoa lebih didasarkan rasa saling percaya antara pekerja dengan pemilik, dari pada kontrak kerja (Ichwan, 2018).

Berbeda dengan etnis Tionghoa yang memiliki semangat tinggi dalam membangun kerajaan bisnisnya, etnis Karo sebagai etnis pribumi juga memiliki hal yang menarik untuk dibahas bagaimana motif ekonomi yang mendasari mereka untuk berusaha. Hal ini tentu menarik melihat bagaimana Etnis Karo ini bertahan dengan adanya pembangunan disekitar Jalan Djamin Ginting. Bahkan etnis Karo tersebut ikut beradaptasi dengan kondisi pembangunan yang ada. Etnis Karo yang terbiasa menjajakan sayuran di era 80-an berubah dengan penyediaan layananlayanan yang dibutuhkan oleh mahasiswa sebut saja seperti warnet, rental komputer, cetak foto, kos-kosan dan lain sebagainya. Perubahan ini juga dipicu oleh keberadaan USU yang menjadi pemicu mereka untuk berubah dan pada akhirnya ikut masuk ke dalam pembangunan.

Pemukiman Karo di Medan berlokasi di daerah Kecamatan Medan Baru dan Medan Tuntungan. Tahun 1953 kampungkampung ini masih berada di pinggiran kota dan merupakan akses jalan ke Tanah Karo dari Medan. Mayoritas etnis Karo bekerja sebagai pedagang sayuran, tekstil, dan hasil bumi. Mereka berjualan di pinggiran kota menuju kampung halaman mereka. Disana mereka dengan mudah menyimpan sayuran-sayuran yang baru datang dari kampung halaman sebelum membawanya ke pasar-pasar pusat kota (Pelly, 1998). Para pendatang baru yang bekerja sebagai petani atau pegawai sering membangun rumah-rumah mereka di sekitar perkampungan menjelang 1981, kelompok etnis karo menjadi populasi mayoritas di kawasan kampung Merdeka, Padang Bulan, Titi Rante, Tuntungan, dan Simalingkar (Pelly, 1998).

Keberadaan sebuah universitas sudah tentu menjadi daya tarik usaha.
Bagaimana kehadiran sebuah institusi pendidikan tentu akan menarik minat anak muda untuk menimba ilmu demi mendapatkan masa depan yang cerah. Kondisi tersebut tentu dapat menjadi peluang bagi siapa saja untuk berusaha dan menghasilkan pundi-pundi uang disana. Terpusatnya etnis Karo yang bermukim di sekitar wilayah Padang Bulan, sejak tahun 50-an ternyata membawa berkah tersendiri. Mereka yang dahulu terbiasa berjualan sayur di Pajak Sore Padang Bulan yang berasal dari hasil ladang dataran tinggi Karo sudah mulai berubah. Etnis karo mulai melihat peluang bisnis yang lebih realistis daripada hanya menjajakan sayuran disana. Kondisi ini sudah pasti terjadi sebagai efek domino keberadaan universitas. Etnis Karo memanfaatkan peluang ini dalam membuka usaha di bidang perlengkapan kuliah, alat tulis kantor, dan jasa ketik yang mulai menjamur.

Sebagai kota tumbuh di sekitar Padang Bulan yang mulai beradaptasi dengan kehidupan kota. Mereka mulai berbaur dengan masyarakat urban perkotaan di Kota Medan. Efek dari pembauran ini etnis Karo di Kota Medan mulai tersegmentasi menjadi tiga kelompok, yang pertama sebagai pedagang atau pengusaha kecil, kedua kelompok terdidik yang bekerja di sektor pemerintahan ataupun swasta di bidang pelayanan dan yang ketiga kelompok residual yang terdiri dari pemuda yang tidak berpendidikan atau biasa sering disebut "preman".

Penelitian ini bermaksud melihat bagaimana, motif ekonomi yang dimiliki etnis karo di kawasan USU berkembang dan bertahan. Bagaimana keberadaan universitas menjadi bagian penting keberadaan etnis Karo di Jalan Jamin Ginting. Namun peniliti tidak berhenti pada penggambaran bagaimana etnis Karo menjadikan USU sebagai lahannya untuk mencari nafkah dengan menjajakan dagangan kebutuhan mahasiswa, namun 
peneliti mencoba melihat sesuatu yang lebih luas dari itu. Peneliti mencoba melihat entitas seperti nilai-nilai yang barangkali masih bertahan dan diadopsi sebagai upaya bagaimana masyarakat etnis Karo bertahan dengan kondisi saat ini.

Alasan-alasan etnis Karo dalam berkembang di Kawasan sekitar USU menjadi bentuk yang tidak terpisahkan dengan konsep motif ekonomi. Peneliti mencoba menemukan alasan tentang motif ekonomi etnis Karo dalam ranah budaya seperti dalam tradisi kerja Tahun ataupun dalam Tradisi Aron yang cukup kental dengan budaya Karo.

Kerja tahun (Tarigan, 2013) dan aron dalam khasanah budaya karo memuat tradisi sekaligus nilai ekonomi yang menggambarkan bagaimana etnis Karo dalam bekerja berkelompok, dalam memanfaatkan ruang-ruang kekerabatan dan menjadikannya sebuah kekuatan. Hal ini seolah sejalan dengan Fukuyama (1995) yang mendefinisikan modal sosial sebagai serangkaian nilai-nilai atau normanorma informal yang dimiliki bersama diantara para anggota suatu kelompok yang memungkinkan terjalinnya kerjasama di antara mereka. Modal sosial sebagai suatu rangkaian proses hubungan antar manusia yang ditopang oleh jaringan, norma-norma, dan kepercayaan sosial yang memungkinkan efisien dan efektifnya koordinasi dan kerjasama untuk keuntungan dan kebajikan bersama. Pandangan tersebut memperlihatkan nilainilai kebersamaan etnis Karo dalam Kerja Tahun dan aron sebagai manifestasi mereka dalam berkembang.

Manifestasi dari kerja tahun dan aron secara tidak langsung memberikan gambaran bagimana modal etnis Karo tersebut dalam memanfaatkan entitas sosial mereka. Hal ini sejalan dengan Alem (2004) yang melalui penelitiannya di Desa Bukit, Beliau memaparkan pembangunan sebenarnya bukan harus sesuatu yang baru tapi dapat mengacu kepada potensi lokal yang sudah ada sebelumnya. Selanjutnya Alem (2004) menemukan jenis modal sosial baru yang dibentuk dan dibangun oleh sebagian kelompok masyarakat yaitu Credit Union yakni usaha simpan pinjam khusus kaum perempuan di Desa Bukit. Institusi ini memunculkan paradigma baru bagi perempuan untuk membangun diri, terutama mengurangi ketergantungan ekonomi kepada pihak laki-laki (suami).

Apa yang dipaparkan Tarigan (2013), Alem (2004), dan Fukuyama (1995) masih dapat diperluas tentan bagaimana etnis Karo dalam memanfaatkan peluang untuk bertahan dan berkembang. Hal ini menyangkut dari pandangan peneliti, bahwa modal sosial saja tidak cukup untuk menghadapi tantangan yang ada. Terutama di wilayah perkotaan. Perlu ada strategi lain yang mendasari bagaimana mereka bertahan dan berkembang dengan Universitas Sumatera Utara menjadi objeknya.

Dalam memahami konteks penelitian ini, motif ekonomi etnis Karo dilihat dalam lima aspek. Aspek tersebut adalah kebutuhan, keuntungan, penghargaan, kekuasaan dan motif sosial. Kelima apek ini menjadi dasar bangunan yang konkret dan jelas.

\section{METODE PENELITIAN}

Penelitian ini bertujuan mendapatkan gambaran secara utuh atas motif ekonomi etnis Karo terhadap pembangunan di kawasan sekitar Universitas Sumatera Utara. Penelitian ini menggunakan pendekatan kualitatif. Dalam penelitian kualitatif menekankan kepada: (1) peneliti sebagai instrumen utama langsung mendatangi sumber data; (2) data yang dikumpulkan cenderung berbentuk kata-kata dari pada angkaangka; (3) penelitian lebih menekankan proses,bukan semata-mata pada hasil; (4)peneliti melakukan analisis induktif cenderung mengungkapkan makna dari keadaan yang diamati; (5) kedekatan 
peneliti dengan responden sangat penting dalam penelitian (Moleong, 2010).

Maleong (2010) mendefinisikan pendekatan kualitatif sebagai penelitian yang dimaksudkan untuk memahami fenomena tentang apa yang dialami oleh subjek penelitian, misalnya perilaku, persepsi, motivasi, tindakan, dll, secara holistik, dan dengan cara deskripsi dalam bentuk kata-kata dan bahasa, pada suatu konteks khusus yang alamiah dan dengan memanfaatkan metode alamiah.

Pendekatan kualitatif digunakan untuk memahami realitas secara utuh mengenai pengalaman-pengalaman dalam iplementasi kebijakan pendidikan karakter. Menurut Creswell dan Patton, penelitian kualitatif lebih terfokus pada proses, arti dan pemahaman tentang pengalaman, serta penghayatan subjektif partisan. Selain itu, penelitian kualitatif juga lebih tertarik pada arti (meaning), yakni upaya partisan menghayati pengalaman dan mengekspresikan dalam hidupnya (Jhon,1994). Penelitian kualitatif kurang mementingkan angka (kuantifikasi), tetapi cenderung kepada interpretasi dan sangat menerima subjektivitasnya terhadap situasi (Cassell, 1994).

Dalam konteks penelitian ini peneliti akan menangkap isu-isu yang berkembang terkait bagaiamana motif ekonomi etnis Karo dan hubungan dengan pembangunan di kawasan sekitar Universitas Sumatera Utara. Peneliti akan mengumpulkan berbagai macam informasi terkait kasuskasus yang tengah berkembang, seperti misalnya isu-isu terkait soal tanah, masalah masalah yang bersifat laten yang terjadi antara masyarakat dan Universitas Sumatera Utara sebagai sebuah institusi. Selain kasus-kasus besar, kisah-kisah beberapa informan tentang bagaimana mereka mengusahakan apa yang mereka miliki dan bagaimana bentuk investasi budaya yang mereka lakukan juga turut menjadi bagian yang dianggap penting untuk ditelaah lebih jauh.
Kasus-kasus yang terkait akan dielaborasi dan dibentuk bangunan yang nantinya mampu menggambarkan bagaimana etnis Karo memanfaatkan keberadaan Universitas Sumatera Utara. Elaborasi ini akan dilakukan dengan melakukan beberapa hal yang berhubungan dengan teknik pengumpulan data.

Untuk memperoleh data secara holistik dan integratif, serta memerhatikan relevansi data dengan tujuan, maka dalam pengumpulan data peneltian ini memakai tiga teknik yang, yaitu: (1) Wawancara mendalam (indept interview); (2) Observasi (observation); (3) Studi dokumen (study document)

Wawancara terstruktur adalah wawancara dengan informan yang peneliti anggap memiliki informasi yang mampu menjawab titik permasalahan. Informan ini adalah hasil elaborasi yang peneliti peroleh dari beragam rekomendasi, beberapa hasil wawancara tidak terstruktur dan wawancara sambil lalu. Beberapa data yang didapat terkait wawancara yang sudah dilakukan, peneliti kategorikan ke dalam matriks yang nantinya memperlihatkan adanya kecederungan informan yang memiliki informasi lebih dan keterbukaan.

Teknik observasi partisipasi ini digunakan untuk melengkapi dan menguji hasil wawancara yang diberikan oleh informan yang mungkin belum menyeluruh atau belum mampu menggambarkan segala macam situasi atau bahkan melenceng. Observasi partisipan merupakan karakteristik interaksi sosial antara peneliti dengan subyek-subyek penelitian. Dengan kata lain, proses bagi peneliti memasuki latar dengan tujuan untuk melakukan pengamatan tentang bagaimana peristiwaperistiwa (events) dalam latar saling berhubungan.

Data penelitian kualitatif kebanyak diperoleh dari sumber manusia melalui observasi dan wawancara, namun data 
dari sumber non manusia, seperti dokumen, foto, dan bahan statistik perlu mendapat perhatian selayaknya. Dokumen terdiri atas tulisan pribadi seperti suratsurat, buku harian, dan dokumen resmi. Dokumen, surat-surat, foto dan lain-lain dapat dipandang sebagai "narasumber" yang dapat diminta menjawab pertanyaanpertanyaan yang diajukan oleh peneliti (Nasution, 2003).

Studi dokumentasi dalam penelitian ini digunakan untuk mengumpulkan datadata yang mendukung untuk memahami dan menganalisis organisasi yang diterapkan di pemerintahan. Data tersebut meliputi personal document (dokumen pribadi) and official document (dokumen resmi). Dokumen pribadi terdiri dari intimate diaries (buku harian), personal letters (surat pribadi), autobiographies (autobiografi). Sedangkan dokumen resmi terdiri atas internal documents, external communication, student record and personnel files (Bogdan, 1998).

Dalam model kegiatan ini kegiatan analisis dibagi menjadi 3 tahap, yaitu pengumpulan data, reduksi data, penyajian data dan penarikan kesimpulan untuk lebih jelas dapat dilihat dibawah:

Reduksi data yaitu proses pemilihan data kasar dan masih mentah yang berlangsung terus menerus selama penelitian berlangsung melalui tahapan pembuatan ringkasan, memberi kode, menelusuri tema dan menyusun ringkasan. Tahap reduksi data yang dilakukan penulis adalah menelaah secara keseluruhan data yang dihimpun dari lapangan mengenai etnis Karo yang mayoritas menguasai lahan dan ekonomi disekitar kawasan Universitas Sumatera Utara, kemudian memilah-milahnya kedalam kategori tertentu.

Seperangkat hasil reduksi data kemudian diorganisasikan kedalam bentuk matriks (display data) sehingga terlihat gambarannya secara lebih utuh. Penyajian data dilakukan dengan cara penyampaian informasi berdasarkan data yang dimiliki dan disusun secara runtut dan baik dalam bentuk naratif, sehingga mudah dipahami. Dalam tahap ini peneliti membuat rangkuman secara deskriptif dan sistematis sehingga dapat menjawab tujuan penelitian.

Verifikasi data penelitian yaitu menarik simpulan berdasarkan data yang diperoleh dari berbagai sumber, kemudian peneliti mengambil kesimpulan yang bersifat sementara sambil mencari data pendukung atau menolak kesimpulan. Pada tahap ini, peneliti melakukan pengkajian tentang kesimpulan yang telah diambil dengan data pembanding teori tertentu. Pengujian ini dimaksudkan untuk melihat kebenaran hasil analisis yang menghasilkan kesimpulan yang dapat dipercaya.

\section{HASIL DAN PEMBAHASAN}

\section{Motif Ekonomi Etnis Karo di Kawasan sekitar USU}

Realitas lapangan meperlihatkan bagaimana etnis karo mengusahakan apa yang mereka yakini. Mulai dari berdagang sendiri hingga menyewakan lahan yang ia pilih menjadi tempat usaha. Selalu saja ada hal yang mampu mereka lihat sebagai sebuah peluang usaha. Pertanyaan muncul ketika setiap usaha itu dilakukan, bagaimana mereka bertahan dan sejauh mana motif dasar mereka dalam pemenuhan kebutuhan itu mendasari apa yang harus mereka lakukan.

Kondisi Etnis Karo di kawasan sekitar Universitas Sumatera Utara tidak jauh berbeda dengan kondisi etnis Karo di beberapa lokasi lainnya. Seperti misalnya di daerah Brastagi, di daerah Deli Serdang dan lain-lain, mereka mayoritas mengusahakan apa yang ia miliki untuk berdagang. Kita masih dapat melihat hari ini bagaimana etnis Karo terkadang turun dari Brastagi untuk mengantarkan sayur ke pusat-pusat pasar di Kota Medan. Berdagang bagi etnis Karo adalah sebuah bagian yang tidak dapat dipisahkan. Mereka sudah hidup dan berpikir untuk 
berdagang sejak kecil. Beberapa dari mereka ada yang melanjutkan usaha orang tuanya ada pula yang mencoba peruntungan lain dengan melihat peluang yang tengah strategis di Kota Medan.

Keberadaan USU sebagai universitas membuka peluang baru bagi etnis Karo yang sebelumnya sudah bermukim di kawasan jl. Dr Mansyur dan Padang Bulan. Wilayah yang dahulunya berupa lahan pertanian padi yang luas membentang, perlahan berubah menjadi sebuah Kota dengan sajian dagangan beraneka ragam. Hal ini merujuk pada pajak-pajak baru yang muncul sejalan dengan keberadaan USU. Pajak-pajak tersebut sering di sebut pajak USU atau pajus.

Terdapat beberapa titik yang disebut dengan pajus ini mulai dengan pajus karona, pajus telokomsel dan pajus masyur. Pajus-pajus ini hadir menyediakan barang-barang kebutuhan mahasiswa mulai dari kebutuhan perluliahan hingga kebutuhan lainnya seperti baju, sepatu dan barang-barang branded lainnya. Pengunjungnya tidak selalu disi oleh mahasiswa, namun warga umum juga sudah mengenal pajus sebagai pajak yang menyediakan barang-barang kebutuhan.

Lokasi Pajus yang paling terkenal dan ramai pengunjung adalah Pajus Karona. Pajus ini memiliki luas 4.000meter persegi. $\mathrm{Di}$ atas lahan ini kios-kios tempat berjualan terbuat dari beton, dimana satu kios dibagun dengan ukuran rata-rata $5 \times 3$ meter. Selain itu untuk memperlancar transaksi jual beli pedagang dengan pembeli tempat ini juga didukung dengan berbagai macam fasilitas, seperti: dua unit mesin ATM, yaitu ATM Mandiri dan ATM BRI, toilet, musholla, dan tempat parkiran. Kelengkapan fasilitas tersebut juga menjadi salah satu hal yang menarik minat pengunjung untuk datang ke Pajus.

Pajus Karona memiliki kurang lebih 150 kios dan 22 stand di atas lahan 4.000meter persegi. Barang-barang yang dijual di tempat ini beraneka macam, seperti: peralatan sekolah/kuliah, buku, majalah, pernak-pernik ponsel, laptop, kacamata, kalung, cincin, gelang, bros, jepit/pita/ikat rambut, anting-anting, pakaian, sepatu, tas, VCD/DVD, dan jajanan kuliner. Hanya ikan dan sayur mayur saja yang tidak ada dijual di sini. Hampir segala jenis benda-benda aksesoris yang biasanya dicari oleh pembeli ada dijual di tempat ini. Tidak hanya pajus, yang hadir sebagai pajak yang meyediakan kebutuhan barang non sayuran, ada juga pajak tradisonal yakni pajak sore yang hadir menyediakan kebutuhan layaknya pajak pada umumnya.

Perkembangan garis pertumbuhan ekonomi juga berkembang di sepanjang jalan Dr. Masyur dan Padang Bulan. Hal ini terlihat dari menjamurnya ruko-ruko yang berdiri di sepanjang jalan tersebut. Mulai dari membuka jasa print foto copy, percetakan, apotik, klinik, waralaba hingga kos-kosan. Perkembangan kawsan ini todak terlepas dari bagaimana etnis Karo yang bermukim di kawasan tersebut memanfaatkan keberadaan USU sebagai universitas yang tentunya menghadirkan orang baru setiap tahunnya. Hal ini pula yang menjadikan usaha disekitar wilayah ini sungguh menjanjikan.

Pengamat ekonomi dari Universitas Negeri Medan (Unimed) M. Ishak mengatakan, kawasan kampus memang merupakan prospek cerah untuk membuka usaha. Hal ini dikarenakan kawasan kampus padat pengunjung, baik mahasiswa maupun masyarakat."Prospek usaha di kawasan kampus sangat menjanjikan, kita lihat saja di kampus mana yang tidak ada para pedagang, baik makanan, penjual kaos, minuman, hingga jasa warnet banyak tumbuh di sekitar kampus," ujar Ishak. Hal ini, kata Ishak, menunjukkan usaha di kawasan kampus masih banyak diterima oleh masyarakat maupun mahasiswa,semakin besar kampus tersebut kata Ishak semakin banyak para pedagang dan pengusaha dadakan yang akan melirik kawasan tersebut(http://www.medanbisnisdaily.com/ 
news/read/2013/05/28/31492/meraup_untung _dari_kawasan_kampus/)

Keberadaan sebuah universitas di sebuah Kota tentu akan menghadirkan efek pembangunan ekonomi di kawasan itu. Masyarakat akan membuka usaha dan memanfaatkan kondisi tersebut. Tidak berbeda dengan hal tersebut, etnis Karo yang bermukim di kawasan sekitaran USU juga melihat peluang itu. Peluang bagi mereka melangsungkan kehidupan dengan membukan usaha. Namun ada hal yang memperlihatkan keunikan dari bagaimana etnis Karo memanfaatkan peluang, hal ini tergambar dari bagaimana mereka memenuhi kebutuhan, memperoleh keuntungan, penghargaan, kekayaan dan hubungan sosial.

\section{Motif dalam memenuhi kebutuhan sendiri}

Keberadaan Universitas Sumatera Utara cukup memberikan berkah bagi mereka yang memiliki lahan di sekitarannya. Sejak kampus terbesar di Sumatera Utara ini berdiri, wilayah di sekitarannya juga terus bergerak maju. Lahan yang dahulu masih terlihat bentangan sawah, kini berubah menjadi pertokoan dan pasar.

Bagi sebagian besar etnis Karo yang bermukim di sekitaran USU, membuka usaha adalah pilihan yang tepat. Peluang dari keberadaan mahasiswa yang hilir mudik setiap tahunnya menjadi pemicu. Keberadaan mahasiswa tentu menjadi keuntungan. Usaha pemenuhan kebutuhan mereka tentu akan meraup keuntungan. Namun tidak sekedar keuntungan namun juga bagaimana memenuhi kebutuhan pribadi.

Upaya untuk memenuhi kebutuhan adalah upaya mereka untuk bertahan. Keinginan untuk berkembang terlihat memiliki resiko karena pada dasarnya ukuran profit bagi mereka adalah ukuran yang tidak untuk dikejar. Hal ini tercermin dari tindakan dan upaya yang bahkan sudah dua puluh tahun berusaha disana tidak menambah outlet ataupun menambah fasilitas.

Kondisi serupa juga diperlihatkan oleh Bang Riki dan Pandia, mereka mengusahakan warung kopi dengan harga murah dan memberikan fasilitas kenyamanan berupa keramahan. Fasilitas seperti wifi merupakan hal yang terkesan berlebihan, selain menambah cos pengeluaran, mereka juga terlihat enggan untuk menaikkan harga jualannya untuk menutupi cos pengeluaran dari penyediaan fasilitas wifi. Alhasil usaha milik mereka lebih terlihat bertahan dan berguna untuk saving mereka ditengah kondisi kebutuhan mereka daripada berkembang.

Sisi menarik dari pembahasan motif ekonomi keempat informan yang memiliki motif pemenuhan kebutuhan adalah bagaimana tindakan yang mereka wujudkan sebagai bentuk manifestasi dari motif tersebut.

Pandia dengan warung kopi miliknya sesuai dengan tindakan sosial rasional nilai, dimana tindakan yang ia ambil dalam memenuhi kebutuhan berdasarkan pilihan rasional dirinya dengan kondisi fisiknya yang sudah terkena strok ringan sehingga tidak dapat kerja berat. Pilihan untuk mengusahakan kedai kopi menjadi pilihan yang tepat baginya.

Pandia melihat bahwa usaha kopi adalah usaha yang tidak pernah rugi. Hal ini karena menyajikan air tidak membuatnya rugi besar. Hal ini sesuai dengan pandangan Weber (2000), Dimana tindakan rasional instrumental dilakukan seseorang didasarkan atas pertimbangan dan pilihan sadar yang berhubungan dengan tujuan tindakan itu dan ketersediaan alat yang dipergunakan untuk mencapainya.

Firdaus Ginting dengan rental Playstation miliknya lebih dekat dengan tindakan Afektif menurut pemahaman Weber (2000) dimana tindakan ini lebih didominasi perasaan atau emosi tanpa refleksi intelektual. Tindakan afektif 
sifatnya spontan, kurang rasional, dan merupakan ekspresi emosional dari individu. Hal ini merujuk pada motif Firdaus ketika membuka rental Playstation hanya didasarkan pada pemahaman bahwa mahasiswa yang sering hilir mudik terkadang memerlukan hiburan. Dan beliau mencoba peruntungan dengan membuka rental PS karena melihat peluang tersebut. Kondisi terlihat baik ketika mampu melihat peluang menjanjikan namun Firdaus melupakan refleksi ataupun pemetaan terhadap kondisi lapangan, sehingga rental miliknya sering terlihat sepi pengunjung. Alhasil ia harus bekerja lain untuk memenuhi kebutuhan keluarganya yang terkadang tidak tercukupi dengan keberadaan rental PS miliknya. Kondisi Firdaus lekat dengan tindakan afektif dimana motif yang ia miliki membangun usahanya tidak terlihat kuat dalam pondasinya dan merupakan reaksi spontannya dalam melihat peluang yang dihasilkan dari keberadaan mahasiswa USU.

Riki Sinuhaji dengan warung kopi miliknya dekat dengan tindakan rasional nilai. Hal ini karena alasan utamanya untuk membangun usaha warung kopi itu berangkat dari nilai-nilai yang ia miliki ketika sebelumnya memiliki usaha warung kopi bersama di daerah sibolangit. Berdasarkan kemampuan dan nilai serta tekad yang ia miliki untuk hidup dengan cara yang baik dan menjauhi narkoba. Selain itu Bang Riki juga membangun usahanya dengan nilai-nilai kekeluargaan. Hal ini terlihat dari keengganan ia untuk meminjam uang ke bank untuk membangun usahanya, baginya menjual asset dan meminta bantuan kepada keluarga jauh lebih rasional daripada harus meminjam uang dari bank. Hal ini terlihat dari upaya beliau menjual lahan miliknya di kampung dan dibantu modal oleh adik kandungnya. Weber mengungkapkan bahwa tindakan rasional nilai memiliki sifat bahwa alat-alat yang ada hanya merupakan pertimbangan dan perhitungan yang sadar, sementara tujuantujuannya sudah ada di dalam hubungannya dengan nilai-nilai individu yang bersifat absolut. Tindakan yang dilakukan berdasarkan pertimbangan nilai etika, adat maupun nilai lainnya. Dengan kata lain pertimbangan untuk memulai usaha dengan kemampuan sendiri dan keluarga adalah nilai yang dianut oleh Bang Riki memulai dan bertahan dengan usaha warung kopi miliknya.

Viktor Napitupulu dengan Usaha toko Kelontong miliknya lebih dekat dengan tindakan tradisional dimana beliau memperlihatkan perilaku karena kebiasaan yang diperoleh dari diri sendiri maupun orang lain, tanpa refleksi yang sadar atau perencanaan yang matang. Pak Viktor Napitupulu yang sudah memiliki toko kelontong sejak dua puluh tahun yang lalu sudah terbiasa dengan ketidakberdayaannya membangun usaha ini dibawah bayang-bayang keluarga istrinya. Beliau tidak memiliki perencanaan yang matang untuk mengembangkan usaha ini. Baginya usaha toko kelontong miliknya sudah cukup dengan terpenuhinya kebutuhan keluarganya. Secara tidak langsung tindakan yang dilakukan oleh Pak Viktor Napitupulu terhadap motifnya dalam berusaha berasal dari kebiasaan yang sudah mengakar dalam dirinya selama dua puluh tahun.

\section{Motif Memperoleh Keuntungan}

Mendapatkan laba dari setiap kegiatan ekonomi yang dilakukan adalah tujuan mempelajari ilmu ekonomibagi banyak orang. Hal ini karena ilmu ekonomi yang dimiliki dapat menjadi motif atau penggerak seseorang atau badan untuk mendapatkan laba atau menfaat tambahan sebesar-besarnya.

Satu hal utama yang menjadi alasan kenapa seseorang ingin mendapatkan laba sebesar-besarnya adalah karena keinginan mereka untuk dapat merubah keadaan hidup mereka menjadi lebih baik. Alasan 
inilah yang menjadi salah satu pengertian pasar bebas karena setiap individu yang terlibat didalamnya akan memiliki kesempatan yang sama untuk memperbaiki keadaan hidupnya masingmasing.

Berbeda dengan mereka yang memiliki motif untuk memenuhi kebutuhan, mereka yang memiliki motif memperoleh keuntungan memiliki perbedaan pada sisi etos kerja, perencanaan dan upaya pengembangan bisnis secara sistematis. Karena nilai adalah profit oriented maka dalam pemenuhannya mereka yang memiliki motif keuntungan lebih dekat dengan stretegi bisnis membangun nilai-nilai ekonomi daripada nilai-nilai yang bersifat kekeluargaan, tradisi dan lain sebagainya.

Sitepu (1996) mengungkapkan bahwa etnis Karo merupakan etnis yang kental dengan tradisi namun juga ikut berkecimpung dalam perubahan. Hal ini memiliki maksud, etnis Karo memiliki penghargaan tinggi terhadap nilai budaya, namun dalam kegiatan ekonomi ataupun sesuatu yang bersinggungan dengan pribadi dan pemenuhan kebutuhan, mereka jauh lebih fleksibel melihat apakah tradisi tersebut tepat atau justru mengganggu jalannya bisnis mereka.

Mengurai bagaimana motif ekonomi etnis Karo dalam memperoleh keuntungan pada dasarnya tidak dapat dibedakan dengan prinsip dasar ekonomi, dimana meraih keuntungan sebesar-besarnya. Namun satu hal yang tidak berbeda dengan motif ekonomi dalam pemenuhan kebutuhan, dalam meraih keuntungan etnis Karo juga terkesan memanfaatkan asset yang dimiliki tanpa bergantung pada pinjaman Bank. Hal ini terlihat jelas dari perusahan besar sekelas Karona Group yang tetap memanfaatkan aset yang dia miliki untuk membangun menjadi pajak USU.

Berkaca pada tindakan sosial Weber (2000), motif ekonomi etnis karo dalam meraih keuntungan hanya terlihat dalam satu tipe yakni tindakan sosial rasional instrumental. Hal ini terlihat dari bagaimana mereka merancang usahanya agar terlihat semenarik mungkin dan meraih keuntungan sebesar besar.

$$
\text { Apa yang Weber ungkapkan }
$$

tentangtindakan sosial rasional instrumental yang dilakukan seseorang didasarkan atas pertimbangan dan pilihan sadar yang berhubungan dengan tujuan tindakan itu dan ketersediaan alat yang dipergunakan untuk mencapainya. Tindakan ini dilakukan untuk mencapai tujuan dengan pertimbangan rasional. Pertimbangan yang jelas serta hitunghitungan untung dan rugi menjadi bagian penting dalam menilai tindakan sosial tersebut.

Motif para pemilik usaha etnis Karo di kawasan sekitar USU menggambarkan tindakan sosial yang diambil secara sadar dengan memanfaatkan segala bentuk modal yang ada. Kondisi ini merujuk dari cara mereka mengatur keberadaan usaha mereka mulai dari melihat peluang yang ada, strategi pemasarannya, usaha apa yang dipilih dan memperhatikan resiko yang mungkin muncul dari usaha tersebut.

Hal ini terlihat dari bagaimana usaha warnet yang mulai sepi pengunjung. Beberapa pemilik usaha seperti Edo benarbenar harus memikirkan resiko dari usaha warnetnya tersebut. Salah satunya adalah resiko perubahan kebutuhan mahasiswa. Beliau juga harus cepat menemukan alternative lain jika masih berminat untuk berbisnis di kawasan sekitar Universitas Sumatera Utara.

Hal ini juga sejalan dengan pemilik usaha Karona Group. Beliau melihat peluang dari terbakarnya pajak USU tahun 2010 sebagai bagian dari cara dia mengubah pailit dari keberadaan bus Karona menjadi areal pajak. Pilihan pilihan itu memperlihatkan adanya hitungan matematis mereka dalam merencanakan usaha. Bentuk seperti peluang, strtegi pemasaran, pilihan usaha dan resiko menjadi bagian tidak terpisahkan dari 
bagaimana etnis Karo di kawasan sekitar USU membangun usahanya untuk meraih keuntungan sebesar-besarnya.

\section{Motif untuk Memperoleh Penghargaan}

Penghargaan adalah tentang kepuasan. Itulah kenapa banyak motif yang dilakukan oleh seseorang untuk mendapatkan penghargaan baik dari orang lainnya ataupun dari lingkungan tempat tinggal. Tidak hanya kepuasan, penghargaan juga memiliki pengaruh terhadap status sosial seseorang dan merupakan salah satu bagian penting dari faktor pertumbuhan ekonomi.

Motif ekonomi untuk memperoleh penghargaan dekat dengan bagaimana usaha ataupun tujuan untuk melakukan usaha tersebut menghasilkan prestise. Dimana prestise tersebut merupakan bagian dari sebuah kebanggan. Etnis Karo secara umum hidup dengan bertani, sikap sederhana sudah terpatri dalam alam pikir dan kehidupan sehari-hari mereka. Atas dasar hal tersebut sangat jarang terlihat etnis Karo yang hidup dengan kondisi yang berlebihan.

Etnis Karo yang memiliki usaha di kawasan sekitar Universitas Sumatera Utara sejalan dengan cara hidup etnis Karo pada umumnya. Mereka terbiasa hidup dengan sederhana, hidup dengan kondisi apa adanya. Meskipun usaha yang mereka miliki tergolong maju, mereka tetap hidup dengan cara biasa.

Berangkat dari pandangan Pak Surbakti di atas memperlihatkan bahwa kehidupn etnis Karo di kawasan sekitar Universitas Sumatera Utara sangat bersahaja, jauh dari kesan kesombongan. Kesan inilah yang meberikan gambaran bahwa di kawasan ini tidak ada etnis Karo yang memiliki Motif ekonomi untuk memperoleh penghargaan. Namun jika berbicara kepuasan etnis Karo di Kawasan sekitar Universitas tentu memilikinya hanya saja hal tersebut tidak menjadi motif utama ketika seseorang memiliki usaha. Kepuasan itu hadir ketika seseorang mampu untuk memenuhi kebutuhan hidup dan hal tersebut di syukuri oleh mereka.

Bang Riki Sinuhaji memperlihatkan bagaimana ia bersyukur dengan kondisi yang ia miliki sekarang. Beliau memiliki warung kopi yang ia usahakan sendiri dengan istrinya. Tanpa harus menyewa, membangun usahanya tersebut di lahan peninggalan orang tuanya. Bentuk kepuasan lainnya adalah ketika dia merasa sudah hidup dengan cara yang benar, tidak lagi menjadi pengedar narkoba.

Motif kepuasan berbeda ditunjukkan oleh Pandia, dimana dengan kondisi fisik yang sudak terkena stroke ringan, ia masih mampu untuk membuka warung kopi untuk memenuhi kebutuhan keluarga. Keberadaan rumah kos-kosan miliknya juga menjadi aset yang pada akhirnya beliau syukuri sebagai bagian dari dirinya dan keluarganya bertahan hidup.

Berangkat dari bentuk kepuasan dan rasa syukur Bang Riki dan Pandia di atas memperlihatkan bagaimana motif ekonomi untuk memperlihatkan bagaimana memperoleh penghargaan tidak terlihat sebagai motif ekonomi etnis Karo. Bentuk penghargaan lebih terlihat dari rasa syukur mereka dalam memiliki usaha yang saat ini mereka usahakan. Bagaimana usaha tersebut mampu menjadi cara mereka bertahan hidup dari pembangunan serta perubahan lingkungan khususnya kawasan sekitar USU yang terus berkembang. Berikut bagan yang menggambarkan bagaimana motif itu hadir dengan tindakan.

Motif ekonomi etnis karo dalam meraih penghargaan tidak terlihat. Namun jika dipahami lebih dalam tentang konsep penghargaan yakni tentang kepuasan, maka diperoleh bahwa motif ekonomi etnis Karo di kawasan sekitar USU bersinggungan dengan tindakan sosial Weber (2000) yakni tindakan sosial Rasional Nilai. Hal ini berkaca pada sikap hidup sederhana dan bersahaja etnis Karo, dimana kekayaan dan keberhasilan tidak harus ditunjukkan sebagai bentuk 
penghargaan namun sebagai sebuah bentuk rasa syukur kepada tuhan dan juga puas dengan pencapaian yang sudah mereka raih.

Bentuk rasa syukur kepada Tuhan diapresiasikan dengan ketaatan kepada tuhan seperti rajin beribadah, ramah, suka menolong sesama dan peduli. Hal ini terlihat dari bagaimana mereka membangun usaha itu seperti memulai dengan berdoa dan bersungguh-sungguh dan diikuti niat baik, tulus dan ikhlas.

Bentuk puas dengan pencapaian disini bukan berarti etnis Karo di Kawasan sekitar USU stagnan dengan pencapaian yang mereka raih. Namun lebih bagaimana mereka menghargai usaha-usaha yang mereka lakukan. Menghargai usaha tersebut hadir ketika mereka serius dalam berusaha, mereka meperlihatkan bahwa usaha ini memiliki andil besar dalam kehidupannya. Berangkat dari pemahaman tersebut maka etnis Karo lebih siap ketika berada dalam kondisi sulit.

Rasa syukur dan puas dengan kondisi ini sejalan dengan pemikiran Weber. Dalam tesisnya Weber mengaitkan etika protestan terhadap semangat kapitalis. Menurutnya manusia seringkali dipenuhi dengan usaha terus menerus untuk mencari harta dan uang, untuk mencapai tujuan akhir dari kehidupannya. Perolehan ekonomu tidak lagi dilayankan kepada manusia sebagai alat untuk mendapatkan kepuasan akan kebutuhan materialnya. Atas dasar hal tersebut pedoman-pedoman etis ini oleh individu, wirausahawanwirausahawan atau pekerja-pekerja dalam usaha -usaha kapitalistik modern adalah suatu kondisi bagi berlangsungnya eksistensi kapitalisme sekarang. Kapitalismes sekarang telah didominasi oleh kehidupan perekonomian, mendidik insan-insan ekonomi yang dibutuhkan melalui proses survival of the Fittest dalam bidang ekonomi (Weber, 2000).

Menilik studi-studi dan karya-karya Weber selanjutnya yang cenderung mengambil objek agama, jelas jika The
Protestan Ethic membentuk bagian paling awal dalam penyelidikan Weber yang lebih luas ke dalam agama dunia. Penelitianpenelitian selanjutnya mengenai agama-agama dunia seringkali -bahkan selalu- menggunakan metode dan kerangka kerja The Protestant Ethic. Sumbangan keilmuan semacam ini sangat mempengaruhi perkembangan ilmu-ilmu yang mencakup studi-studi Weber, seperti ilmu hukum, ilmu ekonomi, ilmu sejarah, ilmu agama dan lain-lain (Agung, 2016).

\section{Motif Untuk Memperoleh Kekuasaan}

Motif ini biasanya dilakukan oleh seseorang yang sudah memiliki kecukupan ekonomi namun ingin menambahnya dengan tujuan menguasai ekonomi diberbagai bidang perekonomian lainnya. Motif ini lekat dengan kuasa, dimana untuk memperoleh hal tersebut dibutuhkan modal yang kuat dan didukung dengan kekuatan jaringan yang memadai.

Kekuasaan yang dibahas pada bagian ini adalah kuasa yang berhubungan untuk menguasai sektor ekonomi. Kekuasaan ini dapat diartikan monopoli ataupun sekedar menambah jaringan serta kekuatan bisnis. Pak Surbakti mengungkapkan bahwa etnis Karo adalah etnis yang siap berhadapan dengan tantangan ketika tantangan tersebut datang.

Mengambil pandangan dari pendapat Pak Surbakti di atas, kondisi tersebut memberikan gambaran bahwa Etnis Karo memiliki jiwa bertarung yang tinggi dengan kehidupan. Pertanyaanya bagaimana hubungan jiwa bertarung etnis Karo ini dengan motif ekonomi dalam memperoleh kekuasaan?

Etnis karo yang sebagian besar hidup sebagai petani dan pedagang secara garis besar menunjukkan bahwa mereka termasuk orang-orang yang siap berjudi dengan kondisi hidupnya sendiri. Mereka siap terhadap resiko gagal panen ataupun jualan mereka yang harus bangkrut. Namun ditengah keberanian tersebut, tidak jarang juga mereka sukses dalam 
mengembangkan usaha dan akhirnya Berjaya.

Sebuah representasi bagaimana motif ekonomi etnis Karo dalam memperoleh kekuasaan dapat dilihat dari keberadaan Pajus Karona di Jalan Jamin Ginting. Sebelumnya sudah dijelaskan bagaimana Karona Group melihat peluang besar pasca terbakarnya pajus di tahun 2010. Kemampuan melihat peluang tersebut diiringi dengan keinginan untuk mengembangkan usaha. Kondisi ini terlihat dari berkembang lahan usaha milik Karona Group yang tidak hanya mengelola pajus Karona, namun juga mampu membeli aset lahan pajus Telkomsel menjadi miliknya. Berkembangnya aset milik Karona Group berasal dari bagaimana mereka melihat peluang yang ada ditambah dengan kekuatan jaringan yang mereka miliki.

Sejalan dengan keberadaan Pajus yang berkembang pesat dengan ramainya pelanggan yang hilir mudik juga menambah income bagi usaha perparkiran. Berbeda dengan lokasi lain dimana jasa parkir biasa berada dibawah manajemen perusahaan ataupun diambil alih oleh dinas Perhubungan kota, jasa parker di sekitar Pajus dikelola oleh pemuda setempat.

Hal menarik ketika melihat manajemen perparkiran di sekitar Jalan Dr Mansyur memperlihatkan bahwa adanya monopoli jasa parker disana. Adanya elite lokal yang secara tidak langsung menjadi sosok dalam legalitas jasa parker disana. Hal ini terlihat dari adanya bentuk kerja sama antara pihak pengelola dengan dinas perhubungan Kota Medan.

Motif ekonomi untuk memperoleh kekuasan bersinggungan dengan tindakan sosial rasional instrumental. Hal ini mengingat bahwa mereka yang ingin mengembangkan usahanya tentu memiliki perhitungan yang matang dan strategistrategi tertentu. Berkaca tentang bagaimana memperoleh kekuasaan tersebut maka ada tiga upaya yang paling tidak begitu menonjol dalam tindakan yang etnis Karo ambil dalam mengembankan usaha miliknya.

Kemampuan etnis Karo dalam melihat peluang usaha adalah hal yang paling penting dimiliki ketika ingin memperoleh kekuasaan. Kemampuan Karona Group untuk mengambil resiko merubah terminal busnya menjadi lahan Pajus adalah kemampuan mereka dalam melihat peluang.

Kemampuan untuk melihat peluang harus dibarengi dengan kemampuan untuk mengembangkan usaha. Etnis Karo yang memiliki kebiasaan berjudi dengan kehidupan yang mereka miliki dan usaha yang mereka jalankan sangat lekat dengan hal ini. Usaha tersebut harus berkembang sejalan dengan peuang yang ada. Seperti Pajus Karona yang mampu mengakuisisi pajus di sebelahnya sebagai upaya mengembangkan lahan milik sebagai aset jangka panjang.

Kedua kemampuan di atas dilengkapi dengan kemampuan untuk membangun jaringan. Jaringan disini tidak hanya jaringan antara sesama pedagang namun juga pihak terkait seperti pemerintah, dan pihak lainnya. Kemampuan Bapak Bangkit Sitepu membangun kerja sama dengan pihak-pihak terkait seperti pihak Pajus Karona, dinas perhubungan Kota Medan menjadi berkah bagi pemuda setempat untuk bekerja. Secara tidak langsung Bapak Bangkit Sitepu mampu membangun komunikasi dan menciptakan monopolinya terhadap jasa parkir di sepanjang jalan Jamin Ginting.

\section{Motif Sosial}

Selain sebagai makhluk sosial, ternyata manusia juga merupakan makhluk ekonomi. Motif sosial adalah salah satu hal yang dimiliki oleh manusia dalam kegiatan ekonomi yang dilakukannya dengan tujuan membantu sesama. Hal ini dilakukan sebagai sebuah kesadaran bahwa sejatinya manusia tidak 
bisa hidup seorang diri tanpa adanya hubungan dengan orang lain.

Motif sosial menjadi motif yang mengembangkan nilai-nilai luhur karena sifatnya yang mengajak untuk berbagi dan bekerja sama. Menarik jika melihat bagaimana kehadiran motif sosial dalam persaingan usaha di kawasan sekitar USU. Hal ini terkait dengan bagaimana membangun persaingan yang sehat dengan keberadaan motif sosial yang tidak kalah tinggi.

Motif sosial lekat dengan tiga tipe tindakan sosial Weber, dimana ketiganya dapat diilhami oleh orientasi membuka usaha dengan motif sosial. Namun dari ketiga tipe tersebut, motif sosial lebih dekat dengan tindakan rasional nilai dan tindakan sosial tradisional.

Kedekatan dengan tindakan rasional nilai berasal dari kemampuan etnis Karo sosial menerapkan nilai-nilai kekeluargaan dalam membangun usaha miliknya. Bangunan tersebut terlihat dari usaha yang dirintisnya tetap memakai keluarganya untuk bekerja disana. Ada nilai yang ingin dibangun tentang bagaimana etnis Karo berusaha agar keluarganya juga merasakan dampak dari berkembangnya usaha miliknya.

Kedekatan dengan tindakan sosial tradisional berasal dari factor kebiasaan. Etnis Karo terbiasa menjual aset miliknya kepada keluarganya terlebih dahulu, atau berdiskusi dengan keluarga jika hendak menjual aset miliknya. Etnis Karo tidak terbiasa menggunakan Jasa Bank, dengan kata lain hubungan -hubungan kekerabatan terlihat epic terbangun disana. Hal inilah yang menjadikan tindakan sosial tradisional begitu lekat dengan motif sosial dalam mengembankan usaha miliknya.

\section{Motif yang Mempengaruhi Etnis Karo untuk Bertahan}

Bertahan pada dasarnya merupakan sikap yang defensif dan pasif dalam dunia bisnis dan usaha. Bertahan dengan apa yang seseorang miliki dari usahanya adalah cara terakhir ketika peluang untuk mendapatkan keuntungan besar terlihat mustahil di depan mata. Namun bertahan yang dimaksudkan dalam penelitian ini adalah bertahan dengan kondisi terbaik sebagai pilihan yang paling tepat.

Etnis Karo di kawasan sekitar Universitas Sumatera Utara sebagian besar memilih bertahan dengan apa yang mereka miliki. Sebidang tanah yang mereka miliki diusahakan dengan berbagai macam ragam usaha. Dalam alam pikir mereka jauh anggapan untuk menjual aset mereka di kawasan ini. Faktornya tentu banyak selain melihat bagaimana keberadaan USU yang tidak pernah sepi baik mahasiswa ataupun masyarakat umum. Hal ini diperkuat dengan nilai kuat yang dibangun dalam diri mereka bahwa tanah yang dimiliki bukan untuk dijual melainkan untuk dimanfaatkan sebesarbesarnya untuk kehidupan.

Melihat bagaimana etnis Karo mempertahankan aset miliknya tentu dapat dilihat dari bagaimana motif mereka dalam bertahan. Setidaknya dari lima motif ekonomi yang tersaji sebelumnya, terdapat tiga motif yang sejalan dengan bagaimana mereka bertahan di Kawasan sekitar USU. Ketiga motif tersebut adalah motif ekonomi dalam pemenuhan kebutuhan, motif ekonomi dalam meraih penghargaan, dan motif sosial.

Ketiga motif di atas memperlihatkan energi bertahan etnis Karo dalam mengusahakan aset miliknya disana. Hal ini dapat digambarkan melalui bagan berikut ini. Bagan di bawah ini memberikan gambaran bahwa dalam bertahan di Kawasan sekitar Universitas Sumatera Utara, motif ekonomi etnis Karo berkaitan dengan cara mereka memenuhi kebutuhan, meraih penghargaan dan motif sosial.

Motif ekonomi dalam pemenuhan kebutuhan menggambarkan bagaimana usaha yang etnis Karo jalankan hanya berusaha untuk memenuhi kebutuhan 
sehari-hari. Cukup untuk melengkapi bagaimana mereka bisa hidup untuk menyambung hidup. Dalam motif ini mereka memikirkan bagaimana mengembangkan usaha, namun dalam perencanaan terlihat jauh, sehingga pilihan untuk melaju kea rah perkembangan usaha tidak terealisasi. Model usaha yang menggambarkan etnis Karo hanya berkutat memenuhi kehidupan mereka terlihat dalam usaha mereka hanya membangun tempat kos-kosan, warung kopi dan rental play station dan toko kelontong. Keempat model usaha ini lebih terlihat menggambarkan bagaimana hanya berusaha untuk kebutuhan. Usaha-usaha tersebut memiliki sifat jangka panjang, hal ini juga yang memberikan gambaran bagaimana mereka bertahan dengan aset usaha miliknya.

Motif dalam meraih penghargaan pada dasarnya bukan menjadi motif utama etnis Karo di kawasan sekitar Universitas Sumatera Utara. Motif ini lebih dekat dengan kepuasan yang mereka rasakan dalam menjalankan usaha mereka. Motif ini juga menggambarkan bagaimana etnis Karo bertahan dengan melihat bagaimana mereka bersyukur dan menjadi taat beribadah serta bagaimana mereka merasa puas dengan usaha yang mereka jalani. Bentuk ini terlihat dari usaha yangkurang lebih sama dengan etnis Karo yang memiliki motif untuk pemenuhan kebutuhan.

Motif sosial juga menggambarkan bagaimana etnis Karo bertahan dengan kondisi usaha yang mereka jalani. Hal ini terlihat dari bagaimana mereka enggan untuk meminjam uang ke bank dan memilih untuk menjual aset lain untuk memulai usaha. Motif sosial disini terlihat dari bagaimana jaringan kekerabatan hadir dalam bangunan usaha mereka, bagimana mereka membangun modal dan menggunakan tenaga keluarga dalam menjalankan usaha tersebut.

Berdasarkan lokasi Gambaran bagaimana etnis Karo di kawasan sekitar
Universitas Sumatera Utara yang bertahan terlihat jelas di sepanjang Jalan Pembangunan. Di kawasan ini etnis Karo memilik aset lahan baik yang diusahakan sendiri, menjadi tempat tinggal pribadi dan menyewakannya. Dari observasi dan proses wawancara yang berlangsung terlihat motif ekonomi etnis Karo di kawasan ini lebih memperlihatkan bagaimana mereka mencoba bertahan dengan usaha kecil yang mereka miliki.

Persinggungan antara motif ekonomi etnis Karo di kawasan sekitar USU dalam bertahan dan tipe tindakan sosial yang diambilnya. Tindakan sosial rasional nilai dalam motif ekonomi etnis karo dalam bertahan pada dasarnya terlihat dari cara etnis karo bertahan, meraih penghargaan dan motif sosial. Hal ini karena nilai-nilai kekerabatan, rasa syukur dan hidup dengan sederhana adalah bagian dari kondisi yang menjadi bagian tindakan sosial rasional nilai.

Tindakan sosial afektif terlihat dari motif pemenuhan kebutuhan dan motif sosial. Hal ini terlihat bagaimana mereka melihat peluang namun tidak memiliki perencanaan yang matang. Pada akhirnya usaha tersebut hanya bertahan dengan keuntungan yang cukup untuk kehdiuapn mereka saja.

Tindakan sosial Tradisional terlihat dari motif ekonomi bertahan dan motif sosial. Hal ini diebabkan factor kebiasan yang merka lakukan dalam usaha miliknya lebih mengedepankan bagaimana mereka bertahan dan memanfaatkan jaringan ataupun modal sosial yang tersedia.

Secara garis besar, motif ekonomi etnis Karo dalam bertahan di kawasan sekitar USU atau secara khusus di sepanjang jalan Pembangunan memperlihatkan sikap mereka lebih safety dalam melihat peluang yang hadir. Keberadaan USU yang terus berkembang tidak membuat mereka juga haus akan kekayaan. Hal ini terlihat dari sifat sederhana dan bersahaj yang mereka perlihatkan dalam menjalankan usaha. 
Mereka jauh lebih memahami kondisi sekitar dan melihatnya sebagai bagian yang tentunya harus disyukuri.

Keinginan untuk mengembangkan usaha tentu ada, namun keinginan ini tidak diikuti dengan strategi ataupun modal yang cukup. hasilnya mereka lebih memilih bertahan dengan penghasilan yang cukup dan berjangka panjang daripada menghasilkan pendapatan besar yang sifatnya momentum.

\section{Motif Yang Mempengaruhi Etnis Karo untuk Berkembang}

Berkembang berarti maju dan bergerak. Kondisi ini tentu sangat tepat dengan prinsip ekonomi untuk meraih keuntungan sebesar-besarnya. Berangkat dari pemahaman tersebut, melihat bagaimana etnis Karo di kawasan sekitar Universitas Sumatera Utara berkembang tentu menarik.

Berdasarkan lokasi penelitian, gambaran bagaimana etnis Karo berkembang terlihat di kawasan Jl. Jamin ginting atau dari simpang kampus hingga simpang Harmonika. Pada lokasi ini terlihat bagaimana perkembangan serta bagaimana bisnis itu dibangun dengan prinsip ekonomi.

Dari lima konsep motif ekonomi, kondisi yang memperlihatkan bagaimana etnis Karo untuk berkembang adalah motif untuk meraih keuntungan dan motif untuk meraih kekuasaan.

Motif meraih keuntungan memperlihatkan bagaimanan keuntungan yang besar menjadi alasan utam untuk membuka usaha. Keberadaan USU dengan mahasiswa yang semakin bertambah setiap tahunnya merupakan peluang. Dalam meraih keuntungan tentu diperlukan strategi, hal ini harus benarbenar dipikikan bagaimana strategi yang dilakukan serta bagaimana jenis usaha yang akan dibuka. Dalam motif meraih keuntungan juga sabgat diperhitungkan resiko yang hadir dari usaha tersebut, termasuk kemungkinan merubah jenis usaha yang sekiranya tidak memiliki prospek dan menggantinya dengan peluang usaha yang lebih menjanjikan.

Sejalan dengan motif memperoleh keuntungan, motif untuk meraih kekuasaan juga berhubungan bagaimana mengembangkan usaha tersebut menjadi lebih besar. Seperti usaha foto copy yang berkembang menjadi percetakan, seperti pajus karona yang mampu mengembakan lahan usahanya. Etnis Karo berkembang dengan melihat peluang itu dan mengembankan usaha menjadi lebih besar. Pinjaman modal tidak terhindarkan, dalam tahap ini etnis Karo sedikit lebih bersahabat dengan keberadaan pinjaman bank. Namun pinjaman tersebut bukan menjadi modal utama, modal utam tetap berasal dari aset pribadi ataupun bantuan yang mereka dapatkan dari keluarga.

Bergerak dari motif ekonomi etnis Karo dalam berkembang di kawasan sekitar USU tentu mempengaruhi tindakan yang mereka ambil. Tindakan tersebut sesuai dengan apa yang Weber (2000) ungkapkan, dimana dari empat tipe tindakan sosial tersebut hanya tindakan sosial rasional instrumental yang sejalan dengan hal tersebut.

Keinginan untuk mengembangkan usaha benar-benar meiliki perencanaan yang matang dan trestruktur. Disni etnis karo yang mengembangkan usahanya memiliki target dari setiap tindakan yang ia lakukan. Motif etnis Karo dalam berkembang di kawasan sekitar Universitas Sumatera Utara berhubungan dengan tindakan sosial rasional instrumental. Hal ini terlihat dari perencanaan dan progress dari usaha yang mereka jalankan. Orientasi pada hasil menjadi tuntutan bagaimana mencari keuntungan yang besar dan mengembangkan usaha hingga memiliki cabang.

Secara keseluruhan gambaran yang memperlihatkan bagaimana motif etnis Karo dalam berkembang terlihat dari keberanian mereka berjudi dengan 
kehidupan mereka. Keberanian mereka mengganti usaha jika sudah tidak memiliki propek serta upaya mereka dalam membaca dan mengembankan lahan menjadi alasan kuat bagaimana etos kerja membawa mereka pada kesuksesan. Etos kerja (Ingsih, 2011) yang dimaknai sebagai respon yang dilakukan oleh seseorang, kelompok, atau masyarakat terhadap kehidupan sesuai dengan keyakinannya masing-masing. Setiap keyakinan mempunyai sistem nilai dan setiap orang yang menerima keyakinan tertentu berusaha untuk bertindak sesuai dengan keyakinannya. Bila pengertian etos kerja re-definisikan, etos kerja adalah respon yang unik dari seseorang atau kelompok atau masyarakat terhadap kehidupan; respon atau tindakan yang muncul dari keyakinan yang diterima dan respon itu menjadi kebiasaan atau karakter pada diri seseorang atau kelompok atau masyarakat. Dengan kata lain, etika kerja merupakan produk dari sistem kepercayaan yang diterima seseorang atau kelompok atau masyarakat.

Etos kerja etnis Karo yang disiplin merupakan modal berharga mereka menghadapi tantangan yang dihadapi di kawasan sekitar USU. Putnam mendefinisikan modal sosial sebagai bagian dari organisasi sosial, seperti kepercayaan, norma, dan jaringan, yang dapat memperbaiki efisiensi masyarakat dengan memfasilitasi tindakan terkoordinasi (Putnam, 1993a). Temuan temuan penelitian menunjukan bahwa modal sosial dapat menjadi menyeimbangkan kemalangan ekonomi dan sosial Beberapa bentuk pemikiran Jalan Ketiga menyajikan modal sosial sedikit banyak secara eksplisit sebagai alternatif atas kebijakan kesejahteraan. Sosial demokrat mengusulkan strategi membangun modal sosial untuk menciptakan sistem kesejahteraan yang didasarkan atas prinsip subsidi, melalui dukungan publik secara aktif bagi kelompok swadaya dan bantuan timbal balik.

$\begin{array}{ccc}\text { Sitepu } & (1996) & \text { mengungkapkan } \\ \text { peranan kebudayaan } & \text { karo dalam }\end{array}$ mengantar dan mengatur kehidupan masyarakat karo sangat besar. Kelengkapan unsur yang terdapat dalam kebudayaan karo mampu mendorong dan menciptakan berbagai pengalaman termasuk dalam meningkatkan cara berpikir dan kecerdasan. Hal ini merupakan modal utama mengfhadapi sebuah perubahan. Pada sisi lain, sifat, sikap dan penampilan etnis karo memiliki keistimewaan. Hal ini terlihat dari upaya mereka dalam beradaptasi, seperti ketika adat dan budaya yang terkadang kurang menguntungkan dan menghambat kemajuan, namun hal ini bukan merupakan suatu halangan. Secara diamdiam hal ini mereka tinggalkan bila menurutnya terdapat suatu yang lebih baru dan menguntungkan demi peningkatan hidupnya.

Lebih lanjut Sitepu (1996) mengungkapkan cara berpikir etnis karo dalam menghadapi perkembangan sosial budaya, sosial ekonomi dan ilmu pengetahuan memperlihatkan kehidupan mereka yang tidak statis. Hal ini secara tidak bertahap membawa etnis karo pada sisi kemajuan. Hasil yang dicapai tidak lain karena berguru pada pengalaman, semangat tinggi dan kerja keras.

\section{SIMPULAN}

Etnis Karo bertahan di kawasan sekitar Universitas Sumatera karena memiliki motif kuat dalam diri mereka, bagaimana mereka mempertahankan aset yang mereka miliki. Mereka tidak segan membuka usaha hanya untuk memenuhi kebutuhan dan meraskan kesyukuran dengan hal tersebut. Kemudian bagimana mereka menafaatkan aset dan jaringan keluarga mereka untuk membangun usaha adalah bagian dari cara mereka bertahan. Etnis karo yang bertahan dengan usaha miliknya lebih melihat peluang jangka 
panjang dari keberadaan usaha mereka. Bagaimana usaha ini mampu sebagai investasi jangka panjang yang tidak hanya memenuhi kebutuhannya hari ini namun juga kebutuhan masa depan. Investasi usaha mereka menjadi sebuah tabungan masa depan yang mereka miliki.

Etnis karo berkembang karena melihat peluang yang tersaji. Sebuah karakter yang menjadi temuan lapangan bagaimana etnis karo yang gila dengan judi diiplementasikan dalam cara mereka melihat peluang usaha. USU sebagai peluang disadari sebagai jalan mereka untuk meraup keuntungan dan mengembangkan usaha. Sifatnya mungkin momentum namun mereka mampu menjalankannya dengan baik dan ini terlihat bagaimana usaha mereka berkembang.

Etnis Karo memiliki modal berharga dari cara mereka melihat keberadaan Universitas Sumatera Utara. Baik mereka yang meilih bertahan dan berkembang, keduanya memiliki etos kerja yang sungguh-sungguh. Hal ini merupakan modal berharga bagaimana Modal tersebut menempati kedudukan dan peran yang sangat penting dalam pembangunan. Tidak saja sebagai pengelola dan pelaku pembangunan, tetapi pembangunan itu sendiri harus mampu memberikan mafaat dan perbaikan kehidupan dan kesejahteraan manusia. Adalah perbaikan mutu hidupOleh karena itu keberhasilan pembangunan tidak hanya diukur dengan pertumbuhan ekonomi tetapi yang jauh lebih penting adalah perbaikan mutu hidup manusianya

Modal berharga yang dimilik etnis Karo di kawasan sekitar Universitas Sumatera utara merupakan aspek penting dalam kehidupan sosial yang diharapkan mampu mengubah dinamika sosial dalam berbagai aspek kegiatan. Modal tersebut tidak hanya menyangkut aspek tertentu, tetapi terus berkembang dari aspek kuantitas dan kualitas yang menyangkut berbagai unsur dalam kehidupan masyarakat yang saling berhubungan.

\section{DAFTAR PUSTAKA}

Nugroho, A.M. (2016). Weber: 'Nabi' Etika Protestan, Bapak Verstehen. Pax Humana. Jurnal Humaniora Yayasan Bina Darma. Volume III, No. 1,

Sembiring. A. (2004). Modal Sosial Dalam Komunitas Kuta Etnis Karo Dan Relevansinya Dengan Otonomi Daerah. Digitized by USU digital library.

Bandura, A. (1991). Social Cognitive Theory of SelfRegulation. Organizational Behavior and Human Decision Processes Vol. 50.

Bogdan, R., \& Biklen, S. K. (1998). Qualitative Research for Education: An introduction to theories and methods. Boston: Allyn and Bacon, Inc.

Cassell, C and G. Symon, (1994). Qualitative Methods in Organization Research, London: Sage,

Caedar A.A.W, (2003). Pokoknya Kualitatif: DasarDasar Merancang dan Melakukan Penelitian Kualitatif, cet. 2. Bandung: Kiblat Buku Utama.

Dow, S.C. (2005). Axioms and Babylonian Thought: A Reply. Journal of post Keynesian Economic Vol 27.

Fukuyama, F. (1995). Trust (Kebajikan Sosial Dan Penciptaan Kemakmuran). Yoyakarta: Qalam Press.

Ichwan. R. (2018). Analisis Semiotik Stereotip Etnis Tionghoa Dalam Iklan Televisi (Konstruksi Motif Ekonomi Etnis Tionghoa Dalam Tvc Bukalapak Edisi Imlek Nego Cincai 2017). 2018. Skripsi Universitas Muhammadiyah Yogyakarta. Tidak dipublikasikan.

Jogiyanto, H. (2007) Sistem Informasi Keprilakuan. Jogyakarta: Andi.

Margar, M. (1998). Steedly. Hanging Without A Rope: The Politics of Representation in Colonial And Poscolonial Karoland. UMH Disertation Service.

Moleong, L.J. (2010), Metodologi Penelitian Kualitatif, Bandung: Remaja Rosdakarya.

Nasution, S. (2003). Metode Penelitian Naturatistik Kualitatif, Bandung: Tarsito.

Pelly, U. (1998). Urbanisasi dan adaptasi: peranan misi budaya Minangkabau dan Mandailing. Jakarta: LP3ES,

Ngalim, P. (1990). Belajar Berhubungan Dengan Perubahan Tingkah Laku. Jakarta: PT Rineka Cipta.

Riski, A.A. (2012). Motif Etnis Tionghoa Bekerja Sebagai Pegawai Negeri (Studi Kasus Pada Pns Dan Polisi Etnis Tionghoa Di Sumatera Utara). Skripsi USU tidak dipublikasikan. 
Robert. E.S, (2006). Multiple Case Study Analysis, cet. 2 (New York: Guilford Press, 2006.

Faisal, S. (1990). Penelitian Kualitatif: Dasar-Dasar dan Aplikasi, cet. 1. Malang: YA3.

Siagian, S. (1995). Manajemen Sumber Daya Manusia. Jakarta: Bumi Aksara.

Sitepu, S. (1996). Pilar Budaya Karo. Medan: FKMKSU.

Tarigan. T. (2003). Strategi Ekonomi Suku Karo dalam Menghadapi Tradisi Kerja Tahun (Kerja Tahun Dalam Perspektif Sosiologis Bagian I) Medan: Asosiasi Sosiologi Karo.
Umma, R.H. (2018). Konsep Kapitalisme Max Weber Dalam Perspektif Islam. Jurusan Aqidah Filsafat Islam Fakultas Ushuluddin Dan Filsafat Universitas Islam Negeri Sunan Ampel.Surabaya

Spredley, J.P. (1990). Participant Observation, New York: Polt, Renepart and Winston,

Weber, M. (2000). Etika Protestan dan Semangat Kapitalisme. Surabaya. Pustaka Promethea, 2000 